\title{
Nikica OGRIS*
}

Nekoliko pod vrhom Vošce, na Jureževi planini (nadmorska višina $1.550 \mathrm{~m}$, približno $100 \mathrm{~m}$ pod zgornjim gozdnim robom, $X=410.250 \mathrm{~m}, \mathrm{Y}=151.870 \mathrm{~m}$, gozdni odsek 0205 36C), se je na evropskem macesnu (Larix decidua Mill.) pojavil ožig macesnovih iglic, ki ga povzroča gliva Hypodermella laricis Tub. (Rhytismataceae, Ascomycota). To je parazitska gliva, ki se pogosto pojavlja na območju Alp na nadmorskih višinah več kot $1.000 \mathrm{~m}$. Pojavlja se tudi v Severni Ameriki na ameriških vrstah macesna (Sinclair, 1989).

\section{Simptomi}

Iglice spomladi bledijo, rumenijo in končno porjavijo do poletja (slika 1). Poleti se na odmrlih iglicah oblikujejo črna, podolgovata nespolna trosišča (slika 2) velika $120-340 \times 40-80 \mu \mathrm{m}$, v katerih nastajajo podolgovati, brezbarvni konidiji velikosti $3-5,6 \times 1,2-1,9$ $\mu \mathrm{m}$, ki ne kalijo, niso pomembni za širjenje bolezni in opravljajo vlogo spermacijev (slika 3). Nespolna oblika glive je poimenovana Leptothyrella laricis Dearn. Za bolezen je značilno, da iglice ostanejo pritrjene na kratkih poganjkih še 1-3 leta po odmiranju (Cohen, 1967). Do naslednje pomladi se na odmrlih iglicah razvijejo črni histeroteciji, tj. spolna trosišča, eliptične oblike, ki so bolj ali manj nanizana v vrsti, velika so 0,5-0,8 $\times 0,2-0,3 \mathrm{~mm}$ (Funk, 1985). V histerotecijih se razvijajo aski, ki navadno vsebujejo 4 askospore, brezbarvne, brez prečnih pregrad, $\mathrm{v}$ obliki solz in merijo $70-105 \times 6 \mu \mathrm{m}$.

\section{Biologija}

Gliva $H$. laricis je tako virulentna, da lahko povzroči lokalno epifitocijo. Pojav bolezni je neposredno povezan $\mathrm{z}$ ugodnimi vremenskimi pogoji za njen razvoj. Glavni dejavnik za pojav epifitocije je dolg pomladanski dež, ki pada preden iglice dosežejo določeno starost, tj. iglice morajo biti mlade (Cohen, 1967). Mlade iglice okužijo askospore, ki se sproščajo iz histerotecijev na odmrlih iglicah. Po podatkih iz Avstrije lahko na jakost okužbe vpliva tudi topla pomlad in pojav megle $\mathrm{v}$ času intenzivne rasti iglic v dolžino (Cech, 2004).

\section{Gospodarska škoda}

Bolezen ne povzroča večje gospodarske škode. Lahko pa povzroči popolno osutost mladih macesnov in njihovo smrt. Pri odraslih macesnih lahko zmanjša prirastek in v primerih, ko je pojav bolezni močan in traja več let zapored, lahko vpliva tudi na vitalnost dreves.

\section{Možne zamenjave}

Poškodbe zaradi glive $H$. laricis lahko v zgodnji fazi razvoja bolezni zamenjamo s poškodbami zaradi pozne pomladanske zmrzali. Na iglicah odmrlih zaradi zmrzali se ne oblikujejo črna trosišča, ta se oblikujejo na odmrlih iglicah, obolelih zaradi okužbe z glivo $H$. laricis, šele poleti. Na macesnovih iglicah se pogosto pojavljajo še tri parazitske glive: Mycosphaerella laricina (R. Hartig) Mig., Meria laricis Vuill. in Lophodermium laricinum Duby. Mycosphaerella laricina povzroča bolezen, ki jo imenujemo rjava macesnova pegavost, Meria laricis povzroča merijski osip macesnovih iglic, Lophodermium laricinum povzroča lofodermijski osip macesnovih iglic. Vse omenjene glive lahko razlikujemo po makroskopskih lastnostih neposredno na terenu glede na pojav prečnih prog (demarkacijskih črt) in trosišč na iglicah (slika 4 in 5).

\section{Viri}

Cech T.L. 2004. Nadelschütten der Lärche. Forstschutz Aktuell, 32: $11-13$

Cohen L.I. 1967. The pathology of Hypodermella laricis on larch, Larix occidentalis. American Journal of Botany, 54, 1: 118-124

Funk A. 1985. Foliar fungi of western trees. Victoria, British Columbia, Canadian Forestry service, Pacific forest research centre: 159 str.

Sinclair W.A., Lyon H.H., Johnson W.T. 1989. Diseases of trees and shrubs. Comstock Publishing Associates, a division of Cornell University Press: 512 str.

*Gozdarski inštitut Slovenije, Večna pot 2, 1000 Ljubljana nikica.ogris@gozdis.si 


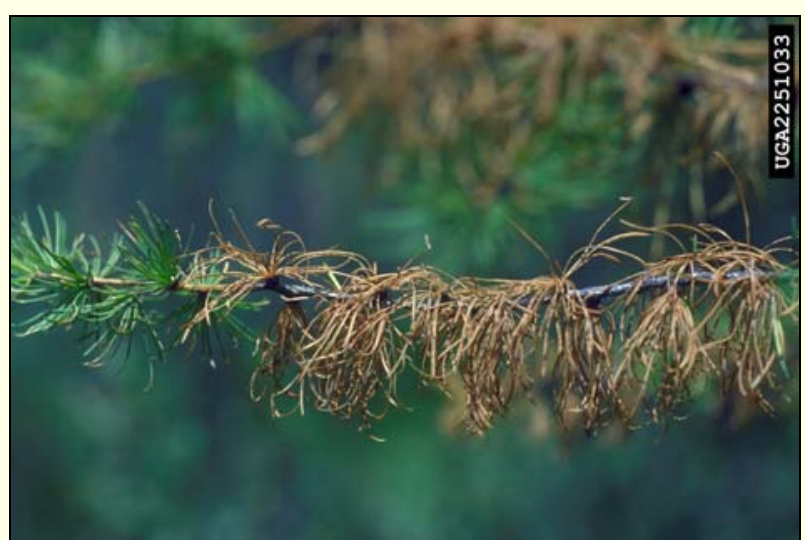

Slika 1: Rumenenje mladih iglic spomladi je prvi simptom za pojav Hypodermella laricis (Foto: USDA Forest Service, Bugwood.org)

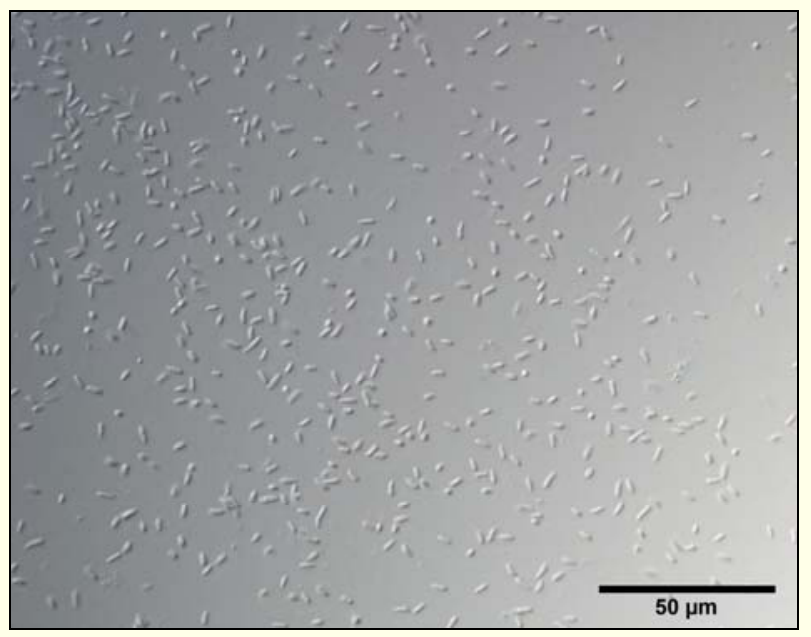

Slika 3: Konidiji nespolnega stadija Leptothyrella laricis (Foto: Nikica Ogris)

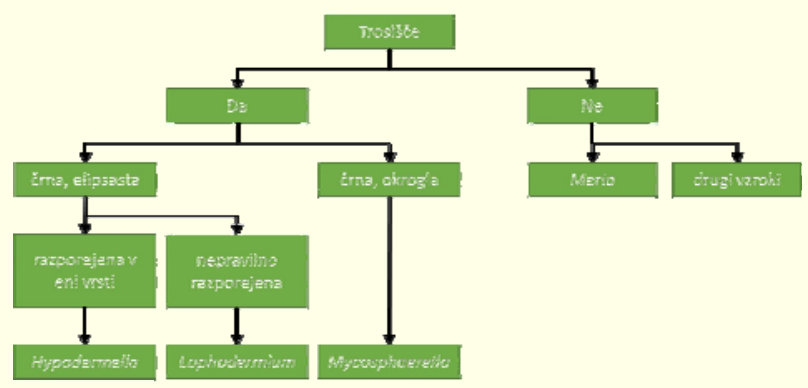

Slika 5: Makroskopsko ločevanje med Hypodermella laricis, Mycosphaerella laricina, Meria laricis in Lophodermium laricinum glede na morfološke značilnosti trosišč (prirejeno po Cech, 2004)

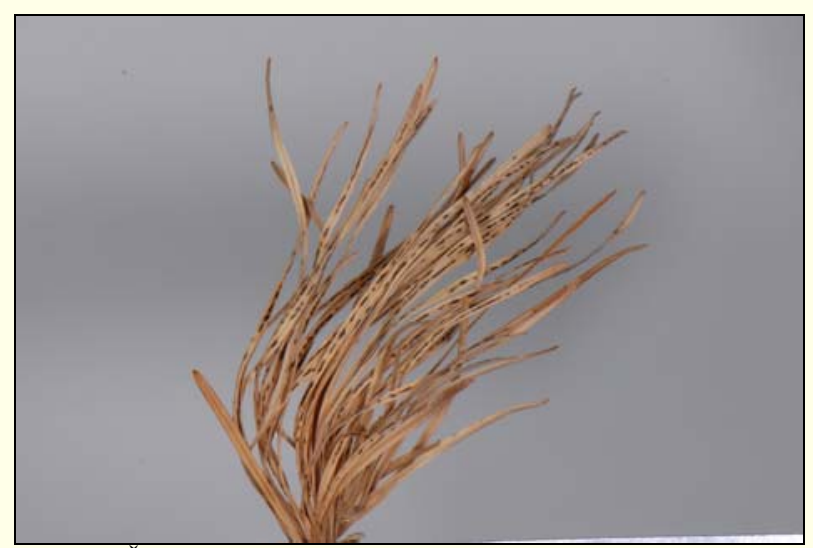

Slika 2: Številna trosišča nespolnega stadija Leptothyrella laricis, ki so črne barve, podolgovate oblike, nanizane ena za drugo po sredini iglice (Foto: Nikica Ogris)

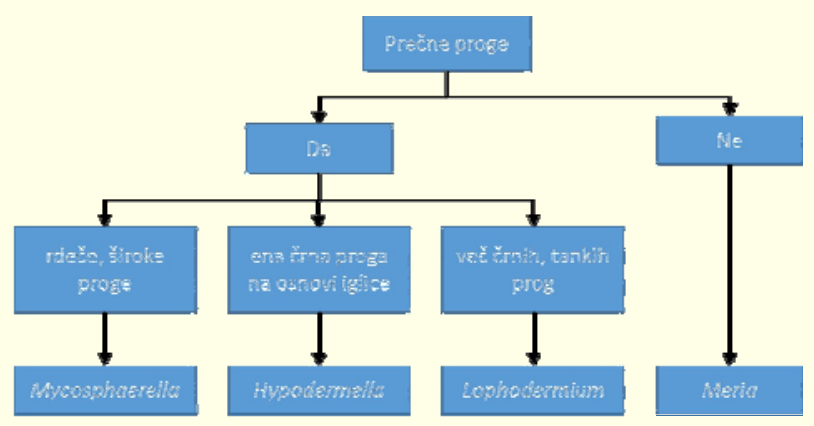

Slika 4: Makroskopsko ločevanje med Hypodermella laricis, Mycosphaerella laricina, Meria laricis in Lophodermium laricinum glede na pojav prečnih prog na iglicah (prirejeno po Cech, 2004) 